\title{
The Roles of Organizational Learning Capability and Firm Innovation in the Relationship between Entrepreneurial Orientation and Firm Performance
}

\author{
Ploychompoo KITTIKUNCHOTIWUT ${ }^{1}$
}

Received: July 9, 2020 Revised: September 06, 2020 Accepted: September 10, 2020

\begin{abstract}
This research aims to examine the relationships among entrepreneurial orientation, organizational learning capability, firm innovation, and firm performance. To achieve a data collection, a mail survey procedure via questionnaire was implemented by using executives or managers of gems \& jewelry industries, textile and clothing industries, leather and accessories, fashion apparel industries in Thailand as the key informants. Of the surveys completed and returned, 388 were usable. Hence, a model with a structural equation was used to evaluate the data survey of 388 respondents. The results reveal that, in terms of the mediating effect, organizational learning capacity and firm innovation can complement each other in order to improve entrepreneurial orientation. Findings show that entrepreneurial orientation improves firm innovation, which in turn improves firm efficiency. Firm innovation acts as a variable mediating between enterprise orientation and firm performance. Our findings contribute to the current emergence of organizational learning capacity that mediated the relationship between entrepreneurial orientation and firm performance. Entrepreneurial orientation is normally a firm performance that enterprises develop which can have use the information available and make an impact. It can be considered through the mediation of organizational learning capability, and firm innovation variable and as stated in previous literature, it can influence firm performance.
\end{abstract}

Keywords: Entrepreneurial Orientation, Organizational Learning Capability, Firm Innovation, Firm Performance

JEL Classification Code: L25, O26, O31

\section{Introduction}

Innovation in the productions and operations of enterprises has become a significant factor for organizational success despite the increased challenges of fierce competition, economic globalization and technological advancement (Lin et al., 2016; Obeidat et al., 2017). To keep up with the highly changing environment, organizations need to adapt the entrepreneurial orientation behaviors such as innovativeness, proactiveness, and risk taking (Kraus, 2013). In the 1970s

${ }^{1}$ First Author and Corresponding Author. Assistant Professor, Mahasarakham Business School, Mahasarakham University, Thailand [Postal Address: Kantarawichai District, Muang City, Maha Sarakham Province, 44150, Thailand]

Email: ploychompoo.k@acc.msu.ac.th

(c) Copyright: The Author(s)

This is an Open Access article distributed under the terms of the Creative Commons Attribution Non-Commercial License (https://creativecommons.org/licenses/by-nc/4.0/) which permits unrestricted non-commercial use, distribution, and reproduction in any medium, provided the original work is properly cited. the concept of entrepreneurial orientation evolved (Edmond \& Wiklund, 2010) and before then, a lot many revisions have been evoked (Wales, 2016). Entrepreneurial orientation is found to represent closely the actual actions of a business firm (Stambaugh et al., 2017) and is usually establish to be certainly linked to firm performance (Wang, 2008).

As Wang (2008), has piercing out, a significant dispatch from the conclusions in the prose on the affiliation between entrepreneurial orientation and performance is that merely examining the through impact of entrepreneurial orientation on firm performance does not offer an ample portrait. Many various mediating and moderating variables have been studied to disentangle the appliance by which entrepreneurial orientation movement's firm performance (Rauch et al., 2009).

Whereas most work reflects that entrepreneurial orientation has a constructive impact on firm performance (Zahra \& Covin, 1995; Lumpkin \& Dess, 1996; Wiklund, 1999) this through affiliation does not appear to be empirically definitive (Slater \& Narver, 2000). One of 
the aims for this may be that secure success is directly dependent on several variables both internal and external to the company (Thoumrungroje \& Tansuhaj, 2005) before that the advantages of entrepreneurial orientation frequently revenue several years to be realized (Zahra \& Covin, 1995; Madsen, 2007). Subsequently, some dependent variables that are more responsive to entrepreneurial orientation should be suggested and certain dependent variable should be considered in command to appreciate the connection between entrepreneurial orientation and firm performance.

On the further influence, and based on Lumpkin and Dess (1996) some relationship between entrepreneurial orientation and performance tends to remain context-specific, i.e. inside or outside impacts effect how high-performance entrepreneurial orientation is configured. They silent support investigation exertions to understand the role of contingency methods in explanation the relationship between entrepreneurial orientation and firm performance, given prior research on these factors. Studies will concentrate on defining the fundamental mechanisms that assess the influence of enterprise-led performance orientation (Zahra et al., 1999). In particular, entrepreneurial operations could be sustained by improving processes of organizational learning and knowledge formation, leading to continuous and constructive enterprise participation and maintainable development (Floyd \& Wooldridge 1999).

In adding, organizational learning capability canister be characterized as an organization's capability to develop, transference and incorporate information and change its actions in order to enhance its performance (Jerez-Gomez, CespedesLorente, \& Valle-Cabrera, 2005). Organizational learning capability may remain characterized as the organizational then managerial characteristics or factors that encourage or enable an organization to learn (Goh \& Richards, 1997; Chiva et al., 2007). This skill has remained linked completely to variables such as job satisfaction (Chiva \& Alegre, 2009) before performance in innovation (Alegre \& Chiva, 2008).

The limited amount of inside organizational studies that further explain the relationship between entrepreneurial orientation and firm performance have become a methodical gap in this line of research (Gimenez \& Ventura, 2005; Wales et al.,2013). For managers, determining the degree with which their business is entrepreneurial is highly important and recognizing how this is connected to internal business structures, as the organizational learning capacity of these features helps managers to kind their company more commercial.

\section{Literature Review}

\subsection{Entrepreneurial Orientation and Firm Innovation}

Anderson and Eshima (2013) claimed that entrepreneurial orientation refers to entrepreneurs' behavioral tendencies, the management strategies they have embraced, and their strategic decision-making in the business environment. Entrepreneurial orientation has been established and stressed as imperative for businesses to grow and succeed in the competitive and rapidly evolving market setting, regardless of size (Covin, \& Slevin, 1989). Entrepreneurial orientation was recognized as the primary determinant for the performance, productivity and sustainable growth of the firm.

Additionally, innovativeness means the partiality of an organization to involve and stimulate new concepts, innovation, creativity, and innovative processes which may main to new products, services, or technological procedures, as well as the need for innovative, unique, or new solutions to problems and needs (Covin \& Slevin, 1989; Lumpkin \& Dess, 1996; Morris \& Jones, 1999). Lumpkin and Dess (1996) reflect that while innovation may differ in its degree of radically, innovation reflects a fundamental willingness to move away since prevailing knowledges or observes and to venture beyond the current state of the art. New innovations also have a great deal to do with entrepreneurship. Risk-taking is described as a readiness to devote substantial resource to opportunities with fair risk of disaster (Covin \& Slevin, 1989; Lumpkin \& Dess, 1996; Morris \& Jones, 1999). Lumpkin and Dess (1996) find that companies through an entrepreneurial outlook are frequently characterized by excessive risk-taking, such as experiencing weighty liability or making significant resource investments, in the hope of making great revenues by exploiting business opportunities. Proactiveness refers to how a firm relates to market opportunities by seizing initiative and substitute opportunistically to influence trends and, maybe, even create demand (Jogaratnam et al., 1999).

Innovations are implemented as a solution to deviations in inside and outside situations, or as a proactive measure to affect environmental conditions. Innovation is the creation and application of acquaintance in organisations, including knowledge sharing, as well as evidence among workers (Jiménez-Jiménez \& Sanz-Valle, 2011). The value in product and firm innovation has been significant in recent years. An invention is characterized as an idea or concept perceived as novel through a person before an activity (Rogers, 1995). The perceived novelty of the idea decides his or her reaction to it from the point of view of the individual. When the individual's concept is unique it is an invention (Robertson $\& \mathrm{Yu}, 2001)$. An invention is made up of some technological insight of how things can be done better than the existing state of the art (Tyler, 2001).

In fact, for many reasons the firm's invention of a new product capability is significant, Innovation technologies give businesses incentives for growth and expansion into newer markets, as well as enabling firms to gain competitive advantage. Innovation is characterized by itself as the making, 
adoption and implementation of novel concepts, methods, products or services. The process of creativity involves the creation, dissemination and application of new information (Calantone et al., 2002) and the effective implementation of innovative concepts within an organization (Amabile et al., 1996). Here appears to be broad agreement that learning environment, entrepreneurship and firm innovation are closely linked and several researchers have conducted work to determine how they are linked (Hurley \& Hult, 1998; Liu et al, 2002). Entrepreneurial nature focuses on innovation, including innovativeness, risk-taking and proactivity (Baker \& Sinkula, 1999), and can create competitive advantage in dynamic and volatile markets for a company.

\subsection{Organizational Learning Capability}

Organizational learning capacity container be characterized as an organization's ability to function, i.e. the capability to develop, obtain, transmission and implement knowledge, and similarly the capacity to adjust conduct to reproduce the new cognitive condition in order to enhance organizational performance (Jerez-Gomez, CespedesLorente, \& Valle-Cabrera, 2005). Organizational learning ability serves as a initiator of the organizational learning procedure (Goh \& Richards, 1997) understood as tangible and intangible tools of the organization, as abilities that serve as a means of enhancing reasonable advantage and facilitating the organizational learning procedure (Alegre \& Chiva, 2008). For Hsu and Fang (2009), organizational learning capacity is understood as the ability of the company to acquire and transform new information and relate it toward the creation of new products through competitive advantage and great speed of output.

Additionally, Chiva et al. (2007) claim that organizational learning capacity is both an organizational function and an administrative function that occurs in the learning procedure in calculation to promoting the learning procedure within organizations. Camps, Alegre, and Torres (2011) consider this as the nonappearance of constraints or limitations to the cycle of organizational learning. In this context, the organizational learning capability serves as an expediter of organizational learning. Organizations should establish tasks and procedures that encourage or facilitate organizational knowledge-building. Such processes contain socialization, internalization and outsourcing, as well as all activities of management that build an environment favorable to learning (Mbengue \& Sané, 2013). The effect of organizational capability and organizational learning on the financial performance (Hindasah \& Nuryakin, 2020). Such observes are the core of organizational learning capacity, which can be defined as the collection of management practices that promote the learning process, or as a set of apparatuses that enhance the capability of the organization to sustain and increase its performance (Alegre \& Chiva, 2008; Mbengue \& Sané 2013). Furthermore, capability for organizational learning is generally related to firm innovation (Dodgson, 1993). The process by which firms produce a new product is not coincidental, firm innovation researchers put significant emphasis on the organizational learning capability processes. Therefore, any technical innovation needs the capacity to learn organizationally (Antonello \& Godoy, 2011). Innovation entails individuals to gain established expertise and share it within the organization, For Hsu \& Fang (2009), also suggested that the capacity for organizational learning has a positive influence on firm innovation.

\subsection{Entrepreneurial Orientation and Firm Performance Mediated by Organizational Learning Capability}

Firm performance is a multidimensional concept. According to Rivai and Basri (2004), business performance is something that is produced by a company within a certain period with a certain standard. Firm performance is an assessment of the indicators owned. According to Prakosa (2005) (1) Total Sales, (2) Number of New Products, (3) Amount of Profit. Performance (business performance) is at the performance level.

The main role of organizational learning capability is in helping the organization to adapt to changes in its environment by developing and creating new performs and abilities that respond to individuals changes (Berghman et al., 2013). Organizational learning is an active process that allows organizations to adapt rapidly to changes, leading to new behaviors and skills. It is considered the primary method of managing knowledge and enhancing the firm performance (Zhang et al., 2011; Alsabbagh \& Alkhalil, 2016). Rendering to Haase et al. (2015) organizational learning allows organizations to improve and change their behaviors, to adjust their morals in line with revolution and to make decisions about various problems. This group of activities and behaviors comprises of knowledge acquisition and distribution of information that potentially improves the culture of the organization (Salarian et al., 2015). Organizational learning has four dimensions: organizational culture, organizational structure, knowledge sharing and leadership (Haase et al., 2015).

The term competence discusses to funds and abilities. According to Alikhani et al. (2013) organizational learning capability raises to an established of skills and concrete and intangible resources that help the organization to increase a reasonable advantage. Organizational learning capability has similarly remained considered as an organization's ability to acquire knowledge from its external and internal environments, to understand, construe and assimilate new 
knowledge and to store it in a way that makes it available to employees. In addition, this capability is seen to direct firms toward innovation and firm performance (Wang et al., 2015).

\subsection{Entrepreneurial Orientation and Firm Performance Mediated by Firm Innovation}

Entrepreneurial Orientation has usually been related to firm performance (Zahra \& Covin, 1995; Wiklund, 1999; Jogaratnam et al., 1999; Madsen, 2007). Experiential research suggests that the benefits of entrepreneurial orientation frequently income several years to arise (Zahra \& Covin, 1995; Madsen, 2007), and that firm performance be subject to straight on diverse inside and outside organizational contingencies and variables (Thoumrungroje \& Tansuhaj, 2005). In order to model the entrepreneurial orientation-firm performance relationship, other dependent variables that are more directly delicate to entrepreneurial orientation are suggested.

Some authors (e.g., Ireland \& Webb, 2007; Covin \& Miles, 1999; Schumpeter, 1934) debate that entrepreneurial actions have special properties on product, process and managerial innovations. The prose has conventionally considered innovation as an indicator of entrepreneurship (Ireland et al., 2005; Drucker, 1998; Schumpeter, 1934) though no research has empirically analyzed this relationship. As entrepreneurial orientation increases a firm's proactiveness and willingness to take risks and innovate (Zahra et al., 1999) entrepreneurial orientation and firm innovation may be linked. Entrepreneurial orientation may be measured one of the antecedents of innovation.

Firm innovation is a decisive influence in firm performance as an effect of the development of the competitive environment (Cook, 1992; Bueno \& Ordoñez,
2004). The significance of innovation for good long-term business results is now usually acknowledged and has been extensively reported in the literature (Capon et al., 1992; Lemon \& Sahota, 2004; Montalvo, 2006). Consequently, firm performance is considered to have a direct effect on firm innovation (Wheelwright \& Clark, 1992; West \& Iansiti, 2003; Brockman \& Morgan, 2003), and canister be reflected as a more exact dependent variable of entrepreneurial orientation.

\section{Research Framework and Hypothesis Development}

Based on the literature review, the framework of the study is illustrated in Figure 1. The hypothesis is that, the mediating roles of organizational learning capability and firm innovation in the relationship between entrepreneurial orientation and firm performance.

\section{Data Methods}

\subsection{Sample and Data}

The empirical investigation of this study was accomplished on a population of gems \& jewelry industries, textile and clothing industries, leather and accessories, fashion apparel industries in Thailand. Here, all 673 gems $\&$ jewelry industries, textile and clothing industries, leather and accessories, fashion apparel industries in Thailand from https:// www.thaitextile.org/databaseTh/home/ (2020), Thailand were selected as the samples. To achieve a data collection, a mail survey procedure via questionnaire was implemented by using executives or managers of gems \& jewelry industries, textile and clothing industries, leather

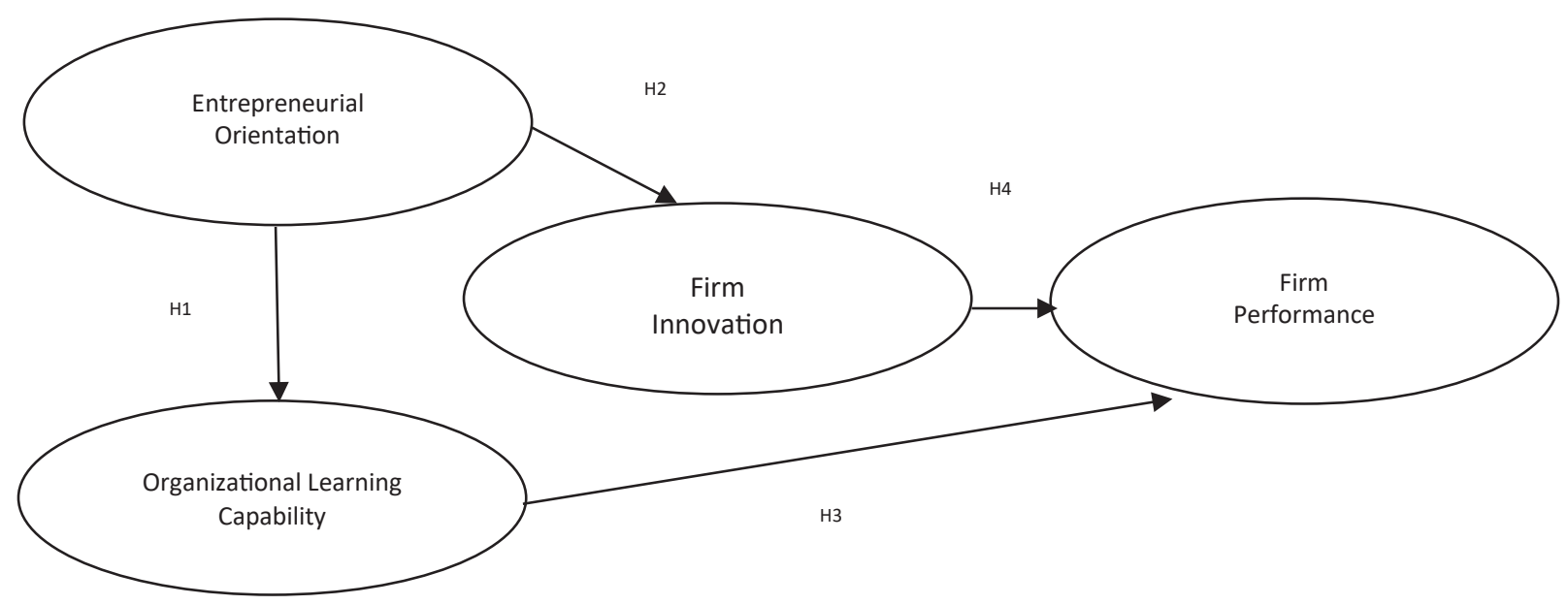

Figure 1: Framework of the Study 
and accessories, fashion apparel industries in Thailand as the key informants. A mail survey procedure via questionnaire was used for data collection. Of the surveys completed and returned, only 388 were usable. The effective response rate was approximately $57.65 \%$. According to Aaker, Kumar, and Day (2001) the response rate for a mail survey, without an appropriate follow-up procedure, and greater than $20 \%$, is considered acceptable. Besides, by using a sample of companies located in a relatively similar geographical, financial, political, socio-cultural, technical and legal space, the impact of variables that cannot be controlled in empirical research is minimized (Adler, 2015). Building on information about the key aspects of this investigation, such as past interactions with interested CEOs scholars and new interviews with CEOs and academicians interested in the subject. Additionally, a non-response bias test was performed by comparing early and late responses. Characteristics of the firms comprise industry types, amount of capital funding, time in business, number of employees, and key informants who self-reported all constructs (Armstrong \& Overton, 1977). As for non-response bias, t-test statistical tests were performed and; the results exhibited no significant differences. Therefore, a non-response bias is of no concern in this data.

\subsection{Methods}

This study surveys a quantitative methodological approach to test the proposed model by using a questionnaire to collect data. The survey instrument is a multi-item measures. All the variables were measured using five-point Likert scales. The key informants were asked for the levels of agreement with statements of items ranging from1 (strongly disagree) to 5 (strongly agree). There were two parts to the data analysis: 1) Analysis of factor loadings and the Cronbach's alpha coefficient for multiple item scales (Table 1). Table 1 shows all the variables that have factor loading scores as between 0.917 - 0.955. Also, Cronbach's alpha for all variables are shown between $0.942-0.956$. The internal consistency is represented through Cronbach's alpha. However, Cronbach's alpha tends to underestimate the internal consistency because of its sensitivity to the number of items in the scale and the sample size (Ringle et al., 2005). As suggested in the literature, values less than 0.95 and greater than 0.7 are desirable (Hair et al., 2013; Ringle et al., 2005). Therefore, all constructs of the validity and reliability of measurement can be applied for further analysis, and 2) Analysis of the three variables of entrepreneurial orientation, the three variables of organizational learning capability, the three variables of firm innovation, and three variables of firm performance. Hypothesis testing was carried out using confirmatory factor analysis (CFA) to measure the validity of the model fit to the empirical data. Testing of the hypotheses was conducted through structural equation model after computing latent variables to become observed variable (Micheels \& Gow, 2012).

\section{The Measurement Model}

\subsection{Entrepreneurial Orientation}

Entrepreneurial orientation was measured using the commonly used nine-item, 7-point scale formulated by Covin and Slevin (1989). A number of analytical papers have used this measurement scale competently (Covin, Green, \& Slevin, 2006; Black, Covin, \& Slevin, 2009; Escribá-Esteve, Sanchez-Peinado, \& Sánchez-Peinado, 2008).

\subsection{Organizational Learning Capability}

In the light of the organizational learning skill theory assumed in our theoretical work, we selected the measuring instrument created by Chiva and Alegre (2009). The instrument contains a series of scales describing, through their products, the theoretical dimensions or latent variables. Using this tool, we conceive with organizational learning capacity as a five-dimensional framework constant with the previous literature: creativity, risk-taking, external environment engagement, dialogue and participatory decision-making. Chiva et al. (2007) concluded an employeebased survey in the ceramic tile industry, validated this measurement scale.

\subsection{Firm Innovation}

Firm innovation is the propensity of any enterprise to encourage creativity, venture into new products and

Table 1: Results of Measure Validation

\begin{tabular}{|l|c|c|}
\hline Items & Factor Loadings & Cronbach's Alpha \\
\hline Entrepreneurial Orientation (EO) & $0.931-0.955$ & 0.956 \\
\hline Organizational Learning Capability (OL) & $0.918-0.931$ & 0.943 \\
\hline Firm Innovation (FI) & $0.931-0.955$ & 0.956 \\
\hline Firm Performance (FP) & $0.917-0.931$ & 0.942 \\
\hline
\end{tabular}


services, invention and development resulting in advanced technological processes, and creative products and services. It is an important means to explore opportunities and is therefore recognized as an important component of entrepreneurship (Covin \& Slevin, 2006). The results of firm innovation comprise product and process innovations; these two types of innovation results are very thoroughly linked (Utterback \& Abernathy, 1975), and constitute a highly complex process that generally involves all functions of the company. A 'product' is a good or service delivered to the consumer, and the way the good or service is created and distributed is a 'process' (Barras, 1986). Product innovation is thus distinct as the product or service introduced to meet consumer or external user needs, and process innovation is understood as a new resource inserted into the production operations or functions (Damanpour \& Gopalakrishnan, 2001). Product innovations are market-oriented and customer-oriented, while process innovations focus on the firm's inside workings and aspire to increase efficiency (Utterback \& Abernathy, 1975).

\subsection{Firm Performance}

In order to assess company success, we inquired general managers to rate the performance of their business over the last three years in relation to competing companies. We used the scale of market success (Venkatraman, 1989).

\subsection{Control Variable}

Firm age and firm size were the control variables. According to Sorensen and Stuart (2000), firm age was used as a control variable. In the overall model, firm size was included as a control variable, as it explains variance in organizational efficiency. Firm size affects the endowment of significant business process inputs such as capital, people and facilities and has been shown to influence the performance of the organization (Tippins \& Sohi, 2003).

\section{Data Analysis}

There were two parts to the data analysis: 1) Analysis of factor loadings and the Cronbach's alpha coefficient for multiple item scales Table 1. Table 1 shows all the variables that have factor loading scores as between $0.917-0.955$. Also, Cronbach's alpha for all variables are shown between $0.942-0.956$. The internal consistency is represented through Cronbach's alpha. However, Cronbach's alpha tends to underestimate the internal consistency because of its sensitivity to the number of items in the scale and the sample size (Ringle et al., 2005). As suggested in the literature, values less than 0.95 and greater than 0.7 are desirable (Hair et al., 2013; Ringle et al., 2005). Therefore, all constructs of the validity and reliability of measurement can be applied for further analysis, and 2) Analysis of the three variables of entrepreneurial orientation, the three variables of organizational learning capability, the three variables of firm innovation, and three variables of firm performance. Hypothesis testing was carried out using confirmatory factor analysis (CFA) to measure the validity of the model fit to the empirical data. Testing of the hypotheses was conducted through structural equation model after computing latent variables to become observed variable (Micheels \& Gow, 2012).

\section{Empirical Results}

\subsection{Results of Structural Equation Model}

The items were developed from existing scales of each variable for this study specifically. The complete measurement model is sketched in Figure 2. IBM-SPSS AMOS program v21 was used to conduct confirmatory factor analysis (CFA). According to Harrington (2008), assessing the measurement model validity occurs when the theoretical measurement model is compared with the reality model to see how well the data fits. The model fit in this study suggests that the dataset fits well with the theoretical factors (see Table 2).

The overall direct and indirect effects related to the entrepreneurial orientation of organizational learning capability, firm innovation, and firm performance are expressed in Table 3. As revealed in Figure 2 and Table 3 , entrepreneurial orientation has a positive effect on organizational learning capability $(\beta=0.462, \mathrm{p}<0.001)$. Hence, hypothesis 1 is supported. Similarly, entrepreneurial orientation has a positive effect on firm innovation $(\beta=0.302, p<0.001)$. Thus, hypothesis 2 is supported. This result demonstrates that entrepreneurial orientation has a positive indirect effect on firm performance through the mediation of organizational learning capability $(\beta=0.168$, $\mathrm{p}<0.001)$. Hence, hypothesis 3 is supported. The results indicate entrepreneurial orientation has a positive indirect effect on firm performance through the mediation of firm innovation $(\beta=0.237, p<0.001)$ is established because of the following conditions (Tippins \& Sohi, 2003). Thus, hypothesis 4 is supported. 


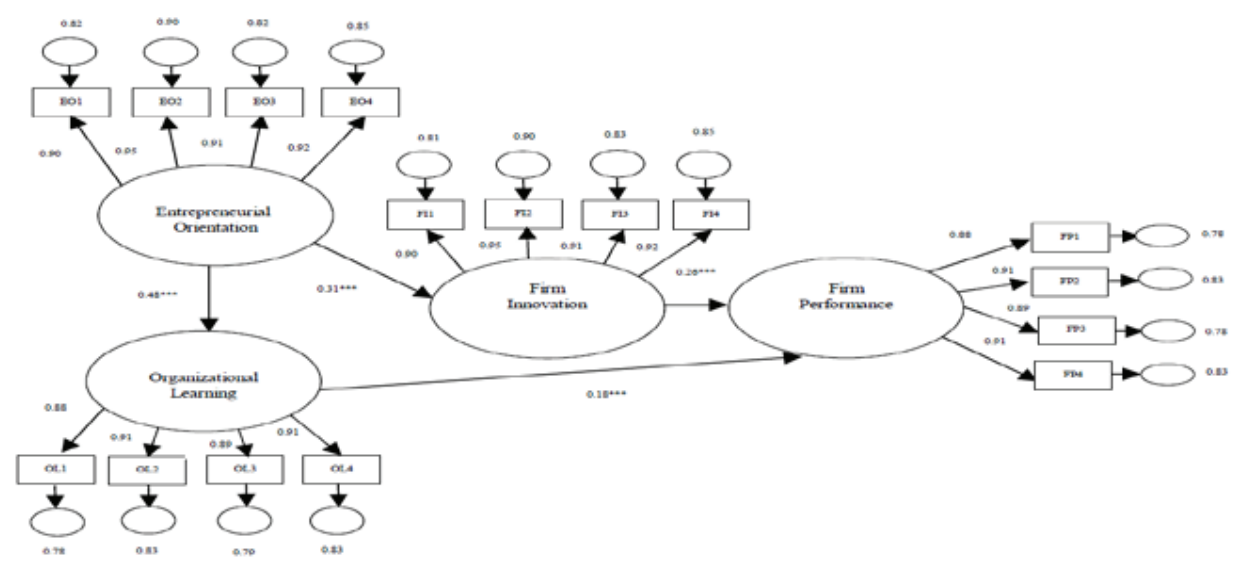

Figure 2: The Structural Equation Model

Table 2: Statistics from Fitting Evaluation

\begin{tabular}{|l|l|c|}
\hline Goodness-of-Fit Measure & \multicolumn{1}{|c|}{ Recommended Value } & Structural Model (result) \\
\hline CMIN/DF & $2.0-5.0$ (Diamantopoulos \& Siguaw, 2000) & 2.367 \\
\hline GFI & $\geq 0.900$ (Diamantopoulos \& Siguaw, 2000) & 0.933 \\
\hline AGFI & $\geq 0.900$ (Diamantopoulos \& Siguaw, 2000) & 0.909 \\
\hline CFI & $\geq 0.900$ (Kelloway, 2015) & 0.979 \\
\hline NFI & $\geq 0.900$ (Schumacker \& Lomax, 2010) & 0.964 \\
\hline RMSEA & $\leq 0.080$ (Schumacker \& Lomax, 2010) & 0.059 \\
\hline TLI & $\geq 0.900$ (Schumacker \& Lomax, 2010) & 0.975 \\
\hline RMR & $\leq 0.050$ (Diamantopoulos \& Siguaw, 2000) & 0.053 \\
\hline
\end{tabular}

Table 3: Direct and Indirect Effects of Variables

\begin{tabular}{|l|l|c|c|c|c|}
\hline Hypothesis & Relationship & Std Beta & Std Error & t-value & Conclusion \\
\hline $\mathrm{H} 1$ & $\mathrm{EO} \rightarrow \mathrm{OL}$ & 0.462 & 0.048 & $9.635^{\star * *}$ & Supported \\
\hline $\mathrm{H} 2$ & $\mathrm{EO} \rightarrow \mathrm{FI}$ & 0.302 & 0.051 & $5.958^{* * *}$ & Supported \\
\hline $\mathrm{H} 3$ & $\mathrm{EO} \rightarrow \mathrm{OL} \rightarrow \mathrm{FP}$ & 0.168 & 0.047 & $3.545^{\star * *}$ & Supported \\
\hline $\mathrm{H} 4$ & $\mathrm{EO} \rightarrow \mathrm{FI} \rightarrow \mathrm{FP}$ & 0.237 & 0.047 & $5.061^{* * *}$ & Supported \\
\hline
\end{tabular}

${ }^{* * *} p<0.001,{ }^{* *} p<0.01$

\section{Conclusions}

Findings show that entrepreneurial orientation improves firm innovation, which in turn improves firm efficiency. Firm innovation acts as a variable mediating between enterprise orientation and firm performance. Our findings significantly contribute to the current emergence of organizational learning capacity that mediated the relationship between entrepreneurial orientation and firm performance (Rauch et al., 2009). Entrepreneurial orientation is normally a firm performance that enterprises develop which can have use the information available and make an impact. It can be considered through the mediation of organizational learning capability, and firm innovation variable and as stated in previous literature, it can influence firm performance. These effects are supported by the results. Specifically, a positive relationship between firm innovation and firm performance was found (Wiklund \& Shepherd, 2003), their results showed significant relation.

In Thailand, particularly among gems \& jewelry industries, textile and clothing industries, leather and accessories industries, fashion apparel industries. By presenting a model demonstrating the impact of 
entrepreneurial orientation has a positive effect on the potential for organizational learning and firm innovation. The findings indicate that, through mediation of organizational learning capacity, entrepreneurial orientation has a positive indirect impact on firm performance. These results revealed that entrepreneurial orientation has a positive indirect impact on firm performance through the mediation of firm innovation. This study's empirical results support the four hypotheses suggested in this research through the mediation analysis, this study also confirms the mediator function of organizational learning ability with firm creativity. Additionally, the findings show that entrepreneurial orientation involved creativity, proactivity, risk taking which can impact firm innovation, and organizational learning capability. This provides for the acquisition, development and use of new knowledge sharing in increasing organizational innovation on toward performance (Muafi, 2020). Firstly, entrepreneurial orientation subsidizes as hegemony to firm performance, with firm creativity mediating the relation between entrepreneurial orientation and firm performance. Second, the findings show that entrepreneurial orientation contributes to firm performance, with organizational learning ability mediating the relationship between organizational orientation and firm performance.

Organizational learning is a fundamental aspect of firm creativity, because the development of new ideas or principles is deemed necessary for the creation of new goods before procedures. Our study contributes to the literature on entrepreneurship by demonstrating the importance of entrepreneurial orientation for the beneficence of organizational learning. This administrative attitude requires certain organizational practices which facilitate their effects on organizations, precisely on performance in innovation. Entrepreneurial orientation with strong firm innovation will intensely move in new product markets and acquire higher risks, requiring them to cope with more complex and changing environments and calling for learning (Bueno et al., 2004). Organizational learning capacity has been noted as a new area of entrepreneurial research (Blackburn \& Kovalainen, 2009), we argue that considerable of its importance to entrepreneurship lies in its effect on innovation performance.

Significantly, the outcomes from this study affirm the contribution of entrepreneurship to firm innovation as a focal point (Bhatt, 2001). Similarly, Chen and Huang (2009), Shujahat et al. (2017) support the role of corporate innovation mediating the relation between entrepreneurial orientation and firm results. Similarly, the results in this study agree with the findings of Lai et al. (2014) which create that the capacity to learn organizationally affects firm performance.

Similarly, the discoveries also sustenance the previous studies suggesting that organizational capabilities focus on product innovation capability, and process innovation capability (Minh Vu, 2020). Their research has shown that sharing knowledge is more appropriate to firm performance innovation when mediated by firm performance (Wang \& Wang, 2012).

\section{References}

Aaker, D. A., Kumar, V., \& Day, G. S. (2001). Marketing Research. New York, NY: John Wiley and Son.

Adler, D., (2015). Doppelte hegemonie. Monograph. https://doi. org/10.5771/9783845265742.

Alegre, J., \& Chiva, R. (2008). Assessing the impact of organizational learning capability on product innovation performance: an empirical test. Technovation, 28(6), 315-326. https://doi.org/10.1016/j.technovation.2007.09.003.

Alikhani, M., Fazlollahtabar, H., \& Mahdavi, I. (2013). Clustering organizational learning capability indices for knowledge sharing in different segments of the firm. International Journal of Management, Knowledge and Learning, 2(2), 209-225.

Alsabbagh, M., \& Alkhalil, A. (2016). The impact of leadership styles on organizational learning (an empirical study on the education sector in damascus city). International Journal of Academic Research in Business and Social Sciences, 6(5), 197-216. https://doi.org/10. 6007/ijarbss/v6-i5/2126.

Amabile, T. M., Conti, R., Coon, H., Lazenby, J., \& Herron, M. (1996). Assessing the work environment for creativity. Academy of Management Journal, 39(5), 1154-1184. https:// doi.org/10.2307/256995.

Anderson, B. S., \& Eshima, Y. (2013). The influence of firm age and intangible resource on the relationship between entrepreneurial orientation and firm growth among Japanese SMEs. Journal of Business Venturing, 28(3), 413-429. https://doi.org/10.1016/j. jbusvent.2011.10.001.

Antonello, C. S., \& Godoy, A. S. (2011). The crossroads of organizational learning: a multiparadigmatic view. $A$ Encruzilhada da Aprendizagem Organizacional: uma Visao Multiparadigmática, 14(2), 310-332.

Armstrong, J. S., \& Overton, T. S. (1977). Estimating non-response bias in mail surveys. Journal of Marketing Research, 14(3), 396-402. https://doi.org/10.1177/002224377701400320.

Baker, W. E., \& Sinkula, J. M. (1999). The synergistic effect of market orientation and learning orientation on organizational performance. Journal of Academy of Marketing Science, 27(4), 411-427. http://doi.org/10.1177/0092070399274002.

Barras, R. (1986). Towards a theory of innovation in services. Research Policy, 15(4), 161-173. https://doi.org/10.1016/00487333(86)90012-0.

Berghman, L., Matthyssens, P., Streukens, S., \& Vandenbempt, K. (2013). Deliberate learning mechanisms for stimulating strategic innovation capacity. Long Range Planning, 46(1- 2), 39-71. https://doi.org/10.1016/j.lrp.2012.11.003.

Bhatt, G. D. (2001). Knowledge management in organizations: Examining the interaction between technologies, techniques, 
and people. Journal of Knowledge Management, 5(1), 68-75. https://doi.org/10.1108/13673270110384419.

Blackburn, R., \& Kovalainen, A. (2009). Researching small firms and entrepreneurship: past, present and future. International Journal of Management Reviews, 11(2), 127-148. https://doi. org/10.1111/j.1468-2370.2008.00254.x.

Brockman, B. K., \& Morgan, R. M. (2003). The role of existing knowledge in new product innovativeness and performance. Decision Sciences, 34(2), 385-419. https://doi.org/10.11 11/1540-5915.02326.

Bueno, E., Pablos, P.O., \& Sanchez, M. P. S. (2004). Innovation and learning in the knowledge-based economy: challenges for the firm. International Journal of Technology Management, 27(6/7), 531-533. https://doi.org/10.1504/ijtm.2004.004902.

Calantone, R. J., Cavusgil, S. T., \& Zhao, Y. (2002). Learning orientation, firm innovation capability, and firm performance. Industrial Marketing Management, 31(6), 515-524.

Camps, J., Alegre, J., \& Torres, F. (2011). Towards a methodology to assess organizational learning capability: A study among faculty members. International Journal of Manpower, 32(5/6), 687703. https://doi.org/10.1108/01437721111158279.

Capon, N., Farley, J. U., Lehman, D. R., \& Hulbert, J. M. (1992). Profiles of product innovators among large U.S. manufacturers. Management Science, 38(2), 157-169. https://doi.org/10.1287/ mnsc.38.2.157.

Chiva, R., Alegre, J., \& Lapiedra, R. (2007). Measuring organizational learning capability among the workforce. International Journal of Manpower, 28(3/4), 224-242. https:// doi.org/10.1108/01437720710755227.

Chiva, R., \& Alegr, J. (2009). Organizational learning capability and job satisfaction: an empirical assessment in the ceramic tile industry. British Journal of Management, 20(3), 323-340. https://doi.org/10.1111/j.1467-8551.2008.00586.x.

Cook, A. (1992). Revolutionizing product development-quantum leaps in speed, efficiency, and quality. $R \& D$ Management, 24(3), 298-300. https://doi.org/10.1111/ j.1467-9310.1994. tb00884.x.

Covin, J. G., \& Slevin, D. P. (1989). Strategic management of small firms in hostile and benign environments. Strategic Management Journal, 10(1), 75-87. https//doi.org/10.1002/ smj.4250100107.

Covin J. G., Green K. M., \& Slevin D. P. (2006). Strategic process effects on the entrepreneurial orientation-sales growth rate relationship. Entrepreneurship Theory and Practice, 30(1), 5781. https://doi.org/10.1111/j.1540-6520.2006.00110. x.

Covin, J. G., \& Miles, M. P. (1999). Corporate entrepreneurship and the pursuit of competitive advantage. Entrepreneurship Theory and Practice, 23(3), 47-63. https://doi. org/10.1177/104225879902300304.

Damanpour, F., \& Gopalakrishan, S. (2001). The dynamics of the adoption of product and process innovations in organizations. Journal of Management Studies, 38(1), 45-65. https://doi. org/ 10.1111/1467-6486.00227.
Diamantopoulos, A., \& Siguaw, J. A. (2000). Introduction LISREL. London, UK: Sage. https://doi.org/10.4135/9781849209359.

Dodgson, M. (1993). Organizational learning: A review of some literatures. Organization Studies, 14(3), 375-394. https://doi.or g/10.1177/017084069301400303.

Drucker, P. F. (1998). The discipline of innovation. Harvard Business Review, 9, 13-15. https://doi. org/10.1002/lt1.40619980906.

Edmond, V.P., \& Wiklund, J. (2010). The historic roots of entrepreneurial orientation research. Historical Foundations of Entrepreneurship Research.142-160. https://doi.org/10.4337/9 781849806947.00015.

Escriba-Esteve, A., Sanchez-Peinado, E., \& Sanchez-Peinado, M. L. (2008). Moderating influences of the firm's strategic orientation-performance relationship. International Small Business Journal, 26(4), 463-489. https://doi. org/10.1177/0266242608091174.

Floyd, W. S., \& Wooldridge, B. (1999). Knowledge creation and social networks in corporate entrepreneurship: the renewal of organizational capability. Entrepreneurship Theory and Practice, 23(3), 123-143. https://doi.org/10.1177/1042258799 02300308.

Gimenez, C., \& Ventura, E. (2005). Logistics-production, logisticsmarketing and external integration: their impact on performance. International Journal of Operations \& Production Management, 25(1), 20-38. https://doi.org/10.1108/001443570510572222.

Goh, S., \& Richards, G. (1997). Benchmarking the learning capability of organizations. European Management Journal, 15(5), 575-583. https://doi.org/10.1016/s0263-2373(97)000364.

Haase, H., Franco, M., \& Félix, M. (2015). Organisational learning and intrapreneurship: evidence of interrelated concepts. Leadership \& Organization Development Journal, 36(8), 906-926. https://doi.org/10.1108/lodj-03-2014-0053.

Hair, J. F., Ringle, C. M., \& Sarstedt, M. (2013). Editorialpartial least squares structural equation modeling: rigorous applications, better results and higher acceptance. Long Range Planning, 46(1-2), 1-12. https://doi.org/10.1016/j. lrp.2013.01.001.

Harrington, N. (2008). Creating a confirmatory factor analysis model. Confirmatory Factor Analysis, 21-35. http://doi. org/10.1093/acprof:oso/9780195339888.003.0002.

Hindasah, L., \& Nuryakin, N. (2020). The relationship between organizational capability, organizational learning and financial performance. Journal of Asian Finance, Economics and Business, 7(8), 625-633. doi:10.13106/jafeb.2020.vol7. no8.625.

Hsu, Y. H., \& Fang, W. (2009). Intellectual capital and new product development performance: the mediating role of organizational learning capability. Technological Forecasting and Social Change, 76(5), 664-667. https://doi.org/10.1016/j. techfore.2008.03.012.

Hurley, R. F., \& Hult, G. T. M. (1998). Innovation, market orientation and organizational learning: an integration and 
empirical examination. Journal of Marketing, 62(3), 42-54. https://doi.org/10.1177/00222429980620030.

Ireland, R. D., Reutzel, C. R., \& Webb, J.W.(2005). Entrepreneurship research in AMJ: what has been published, and what might the future hold?. Academy of Management Journal, 48(4), 556 564. https://doi.org/10.5465/amj.2005.17843937.

Ireland, R. D., \& Webb, J. W. (2007). A cross disciplinary exploration of Entrepreneurship Research. Journal of Management, 33(6), 891-927. https://doi.org/10.1177/0149206307307643.

Jerez-Gomez, P., Cespedes-Lorente, J., \& Valle-Cabrera, R. (2005). Organizational learning capability: a proposal of measurement. Journal of Business Research, 58(6), 715-725. https://doi. org/10.1016/j.jbusres.2003.11.002.

Jimenez-Jimenez, D., \& Sanz-Valle, R. (2011). Innovation, organizational learning, and performance. Journal of Business Research, 64(4), 408-417. https://doi.org/10.1016/j. jbusres.2010.09.010.

Jogaratnam, G., Tse, E. C., \& Olsen, M. D. (1999). An empirical analysis of entrepreneurship and performance in the restaurant industry. Journal of Hospitality and Tourism Research, 23, 339353. https://doi.org/10.1177/109634809902300401.

Kraus, S. (2013). The role of entrepreneurial orientation in service firms: Empirical evidence from Austria. The Service Industries Journal, 33(5), 427-444. https://doi.org/10.1080//02642069.2 011.622373 .

Kelloway, E. K. (2015). Using Mplus for Structural Equation Modeling; AResearcher's Guide. (2nd ed.). Thousand Oaks, CA: Sage Publications. https://doi.org/10.4135/9781483381664.

Lai, Y.-L., Hsu, M.-S., Lin, F.-J., Chen, Y.-M., \& Lin, Y.-H. (2014). The effects of industry cluster knowledge management on innovation performance. Journal of Business Research, 67(5), 734-739. https://doi.org/10.1016/ j.jbusres.2013.11.036.

Lemon, M., \& Sahota, P. S. (2004). Organizational culture as a knowledge repository for increased innovative capacity. Technovation, 24(6), 483-498. https://doi.org/10.1016/s01664972(02)00102-5.

Lin, H., Zeng, S., Liu, H., \& Li, C. (2016). How do intermediaries drive corporate innovation? A moderated mediating examination. Journal of Business Research, 69(11), 4831-4836. https://doi.org/10.1016/j.jbusres.2016.04.039.

Liu, S. S., Luo, X., \& Shi, Y. (2002). Integrating customer orientation in organizations -in- transition: an empirical study. International Journal of Research in Marketing, 19(4), 367382. https://doi.org/10.1016/s0167-8116(02)00098-8.

Lumpkin, G. T., \& Dess, G. G. (1996). Clarifying the entrepreneurial orientation construct and linking it to performance. The Academy of Management, 21(1), 135-172. https://doi. org/10.5465/amr.1996.9602161568.

Madsen, E. L. (2007). The significance of sustained entrepreneurial orientation on performance of firms-a longitudinal analysis. Entrepreneurship and Regional Development, 19(2), 185-204. https://doi.org/10.1080/08985620601136812.
Madsen, E. L. (2007). The significance of sustained entrepreneurial orientation on performance of firms- A longitudinal analysis. Entrepreneurship and Regional Development, 19(1), 185-204. https://doi.org/10.1080/08985620601136812.

Mbengue, A., \& Sane, S. (2013). Organizational learning capacity: theoretical analysis and empirical study in the context of official development aid project teams. Canadian Journal of Administrative Sciences / Revue Canadians des Sciences de administration, 30(1), 26-39. https://doi.org/10.1002/cjas.1238.

Micheels, E. T., \& Gow, H. R. (2012). The value of a positional advantage for agricultural SMEs, Small Enterprise Research, 19(2), 54-73. https://doi.org/10.5172/ser.2012.19.2.54.

Minh Vu, H. (2020). A review of dynamic capabilities, innovation capabilities, entrepreneurial capabilities and their consequences. Journal of Asian Finance, Economics and Business, 7(8), 485494. doi:10.13106/jafeb.2020.vol7.no8.485.

Montalvo, C., (2006). What triggers change and innovation?. Technovation, 26(3), 312-323. https://doi.org/10.1016/j. technovation.2004.09.003.

Morris, M.H., \& Jones, F., F. (1999). Entrepreneurship in established organizations: the case of the public sector, Entrepreneurship Theory and Practice, 24(1), 71-90. https:// doi.org/10.1177/104225879902400105.

Muafi, M. (2020). A nexus among strategic orientation, social network, knowledge sharing, organizational innovation, and MSMEs performance. Journal of Asian Finance, Economics and Business, 7(6), 327-338. doi:10.13106/jafeb.2020.vol7. no6.327.

Obeidat, B., Hadidi, A., \& Tarhini, A. (2017). Factors affecting strategy implementation: A case study of pharmaceutical companies in the Middle East. Review of International Business and Strategy, 27(3), 386-408. https://doi. org/10.1108ribs-10-2016-0065.

Prakoso, B. (2005). Pengaruh orientasi pasar, inovasi dan orientasi pembelajaran terhadap kinerja perusahaan untuk mencapai keunggulan bersaing (Studi empiris pada industri manufaktur di semarang). Jurnal Studi Manajemen dan Organisasi, 2(1), 35-37.

Ratna J.(2010). Factors affecting bioavailability and bioequivalence. Journal of Bioequivalence \& Bioavailability, 1(1). https:// doi. org/10.4172/0975-0851.1000087.

Rauch, A., Wiklund, J., Lumpkin, G. T., \& Frese, M. (2009). Entrepreneurial orientation and business performance: an assessment of past research and suggestions for the future. Entrepreneurship: Theory and Practice, 33(3), 761- 787. https://doi.org/10.1111/j.1540-6520.2009.00308.x.

Ringle, C. M., Wende, S., \& Will, S. (2005). Smart PLS 2.0 (M3) Beta. Hamburg, Germany: Smart PLS GmbH.

Rismawati, S. E., \& Mattalata, S. E., (2018). Performance evaluation: performance appraisal on the basis of futureoriented work performance. Bangkok, Thailand: Celebes Media Perkasa. 
Robertson, P. L., \& Yu, T. F. (2001). Firm strategy innovation and consumer demand: a market process approach. Managerial and Decision Economics, 22(4-5), 183-199. https://doi. org/10.1002/mde.1016.

Rogers, E. M. (1995). Diffusion of innovations: modifications of a model for telecommunications. Die Diffusion von Innovationen in der Telekommunikation, 25-38. https://doi.org/10.1007/9783-642-79868-9_2.

Salarian, M., Baharmpour, K., \& Habibi, S. (2015). Organizational commitment and its relationship with organizational learning (case study: general directorate of ports and maritime of mazandaran province). International Journal of Life Science, $5(6), 67-73$.

Schumacker, R. E., \& Lomax, R. G. (2010). A beginner's guide to structural equation modeling ( $3 r d$ ed.). Mahwah, NJ: Lawrence Erlbaum Associates.

Schumpeter, J. A. (1934). The theory of Economic Development. Cambridge. MA: Harvard University Press.

Shujahat, M., Sousa, M. J., Hussain, S., Nawaz, F., Wang, M., \& Umer, M. (2017). Translating the impact of knowledge management processes into knowledge-based innovation: the neglected and mediating role of knowledge-worker productivity. Journal of Business Research, 94, 442-450. https://doi.org/10.1016/j.jbusres.2017. 11.001.

Slater, S. F., \& Narver, J. C. (2000). The positive effect of a market orientation on business profitability: a balanced replication. Journal of Business Research, 48(1), 12-32.

Sorensen, J. B., \& Stuart, T. E. (2000). Aging, obsolescence and organizational innovation. Administrative Science Quarterly, 45(1), 81-112. https://doi.org/10.2307/2666980.

Stambaugh, J. E., Martinez, J., Lumpkin, G. T., \& Kataria, N. (2017). How well do EO measures and entrepreneurial behavior match?. International Entrepreneurship and Management Journal, 13(3), 717-737. https://doi.org/10.1007/s11365-0160432-5.

Thailand Textile Institute. (2020). Thai textile. Retrieved January 20, 2020, from https:/www.thaitextile.org/th/home/.

Thoumrungroje, A., \& Tansuhaj, P. (2005). Entrepreneurial strategic postur, international diversification and firm performance. The Multinational Business Review, 13(1), 55-73. https://doi. org/10.1108/1525383x200500003.

Tippins, M. J., \& Sohi, R. S. (2003). IT competency and firm performance: is organizational learning a missing link?. Strategic Management Journal, 24(8), 745-761. https://doi. org/10.1002/smj.337.

Tyler, B. B. (2001). The complementarity of cooperative and technological competencies: A resource based perspective. Journal of Engineering and Technology Management, 18(1), 1-27. https://doi.org/10.1016/s0923- 4748(00)0031-x.
Utterback, J. M., \& Abernathy, W.J. (1975). A dynamic model of product and process innovation. Omega, 3(6), 639-656. https:// doi.org/10.1016/0305-0483 (75)90068-7.

Venkatraman, N. (1989). The concept of fit in strategy research: Toward verbal and statistical correspondence. Academy of Management Review, 14(3), 423-444. https://doi.org/10.5465/a mr.1989.4279078.

Wales, W. J. (2016). Entrepreneurial orientation: a review and synthesis of promising research directions. International Small Business Journal, 34(1), 3-15. https://doi. org/10.1177/0266242615613840.

Wales, W. J., Gupta, V. K., \& Mousa, F. T. (2013). Empirical research on entrepreneurial orientation: an assessment and suggestions for future research. International Small Business Journal, 31(4), 357-383. https://doi.org/10.1177/0266242611418261.

Wang, C. L. (2008). Entrepreneurial orientation, learning orientation, and firm performance. Entrepreneurship Theory and Practice, 32(4), 635-657. https://doi/10.1111/j.1540-6520.2008.00246. $\mathrm{x}$.

Wang, K., Hermens, A., Huang, K., \& Chelliah, J. (2015). Entrepreneurial orientation and organizational learning on SMEs' innovation. International Journal of Organizational Innovation, 7(4), 11-22.

Wang, Z., \& Wang, N. (2012). Knowledge sharing, innovation and firm performance. Expert Systems with Applications, 39(10), 8899-8908. https://doi.org/10.1016/j.eswa.2012.02.017.

West, J., \& Iansiti, M. (2003). Experience, experimentation, and the accumulation of knowledge: The evolution of R\&D in the semiconductor industry. Research Policy, 32(5), 809-825. https://doi.org/10.1016/s0048-7333(02)00090-2.

Wiklund, J. (1999). The sustainability of entrepreneurial orientation- performance relationship. Entrepreneurship Theory and Practice, 24(1), 37-48. https://doi.org/10.1177/10 4225879902400103.

Wiklund, J., \& Shepherd, D. (2003). Knowledge-based resources, entrepreneurial orientation, and the performance of small and medium-sized business. Strategic Management Journal, 24(13), 1307-1314. https://doi.org/10.1002/smj.360.

Zahra, S. A. \& Covin, J. G. (1995). Contextual influences on the corporate entrepreneurship-performance relationship: a longitudinal analysis. Journal of Business Venturing, 10(1), 4358. https://doi.org/10.1016/0883-9026(94)00004-e.

Zahra, S. A., Nielsen, A. P., \& Bogner, W. C. (1999). Corporate entrepreneurship, knowledge, and competence development. Entrepreneurship: Theory and Practice, 23(3), 169-189.

Zhang, X., Cao, Q., \& Tjosvold, D. (2011). Linking transformational leadership and team performance: a conflict management approach. Journal of Management Studies, 48(7), 1586-1611. 